\title{
INTRODUCTION
}

\section{Fragmented and Absorptive Regulation: A Conceptual Framework to Understand Food Safety Regulatory Governance in China}

Peng Liu

School of Public Administration and Policy,

Renmin University of China, China

Liang Ma

School of Public Administration and Policy,

Renmin University of China, China

Xun $\mathrm{Wu}$

Hong Kong University of Science and Technology,

Hong Kong, China

Acknowledgement: As the co-editors of this Special Issue, the authors are listed alphabetically. This research is supported by the Major Program of Social Science Foundation of China [18ZDA112].

\section{Abstract}

In recent years China's food safety regulatory governance has become a major research topic for discussion, but a conceptual framework to understand it systematically is still absent. This article theorizes the existing studies on this topic by using a new conceptual framework. After a systematical review on the current literature, we introduce a new conceptual framework to distinguish regulatory regimes by two dimensions: internal coordination and external collaboration. We stress that China's food safety regulatory regime is characterized by internal fragmentation and external absorptiveness, which has a low coordinated internal system and a state-led external structure. On one hand, China's food safety regulatory regime is fragmented both horizontally and vertically, and strong regulatory coordination is greatly needed. On the other hand, the governmental institution system is still playing a dominant role, 
and the voices of market and social organizations are still weak in the regulatory process. This conceptual framework does not only make sense to explain China's food safety regulation, but also is insightful to understand regulatory reforms in other sectors and contexts. It can also shed light on the future development of China's food safety regulatory governance. As the introduction piece of this special issue, we also introduced the five articles and then discussed their relevance to this conceptual framework.

Keywords: Food safety; regulatory regime; internal coordination; external collaboration; China

\section{Regulación fragmentada y absorbente: un marco conceptual para comprender la gobernanza regulatoria de la seguridad alimentaria en China}

\section{RESUMEN}

En los últimos años, la gobernanza reguladora de la seguridad alimentaria de China se ha convertido en un tema de investigación importante para el debate, pero aún no existe un marco conceptual para comprenderlo de manera sistemática. Este artículo teoriza los estudios existentes sobre este tema utilizando un nuevo marco conceptual. Luego de una revisión sistemática de la literatura actual, presentamos un nuevo marco conceptual para distinguir los regímenes regulatorios en dos dimensiones: la coordinación internacional y la colaboración externa. Destacamos que el régimen regulador de la seguridad alimentaria de China se caracteriza por la fragmentación interna y la capacidad de absorción externa, que tiene un sistema interno poco coordinado y una estructura externa dirigida por el Estado. Por un lado, el régimen regulador de la inocuidad de los alimentos de China está fragmentado tanto horizontal como verticalmente, y es muy necesaria una fuerte coordinación regulatoria. Por otro lado, el sistema de instituciones gubernamentales sigue desempeñando un papel dominante y las voces del mercado y las organizaciones sociales aún son débiles en el proceso regulatorio. Este marco conceptual no solo tiene sentido para explicar la regulación de seguridad alimentaria de China, sino que también es útil para comprender las reformas regulatorias en otros sectores y contextos. También puede arrojar luz sobre el desarrollo futuro de la gobernanza reguladora de seguridad alimentaria 
de China. Como parte de la introducción de este número especial, también presentamos los cinco artículos y luego discutimos su relevancia para este marco conceptual.

Palabras clave: Seguridad alimenticia; régimen de regulación; coordinación interna; colaboración externa; porcelana

碎片化的吸纳式监管：一项分析中国食品安全监管治理 的概念框架

\section{摘要}

近年来, 中国的食品安全监管治理已成为一个重要的研究探 讨主题, 但仍然缺失的是一个对其加以系统性理解的概念框 架。本文通过提出一项新的概念框架, 对关于该主题的现有 研究进行理论化。对现有文献进行系统性综述后, 我们引入 一项新的概念框架, 从两个维度区分监管制度：内部协调和 外部协作。我们强调, 中国的食品安全监管制度具有内部碎 片化和外部吸纳性（external absorptiveness）两个特征, 这种 制度拥有一个低协调程度的内部系统和一个由国家领导的外 部架构。一方面, 中国的食品安全监管制度在水平和垂直方 向都呈现碎片化, 并且特别需要强有力的监管协调。另一方 面, 政府制度系统仍然发挥主导作用, 并且市场和社会组织 的意见在监管过程中仍然影响力不足。该概念框架不仅能解 释中国的食品安全监管, 并就理解其他部门和情境中的监管 改革而言也具有意义。该框架还能阐述中国食品安全监管治 理的未来发展。作为本期特刊的导论, 我们还介绍了 5 篇文 章，并探讨了这5篇文章对该概念框架的相关性。

关键词: 食品安全, 监管制度, 内部协调, 外部协作, 中国

\section{Introduction: Food} Safety Regulatory

\section{Governance in China}

s the most populous develop-
ing country in the world, Chi-
na has regarded food security and safety as a predominant issue for its socioeconomic development and social governance. After a series of notorious scandals since 2000 , especially the melamine milk powder incident in 2008 , food safety has become one of the highest social problem Chinese 
citizens are concerned about (Yasuda, 2018; Liu \& Ma, 2016). Unsafe food has definitely brought possible risks not only to people's life quality, but also to the legitimacy of its state governance (Wu, Yang, \& Chen, 2017). Therefore, President Xi Jinping has acknowledged the significance of food safety regulation to the ruling party's long-term governing capacity and legitimacy, to the extent that he instructed the governance of the country's food safety system to be based on a 'four-strictest' principle: the strictest possible safety standards, regulation, penalty, and accountability. ${ }^{1}$ In addition, as one of the largest world food producers, China exports billions of tons of foods to other countries and regions every year. The effectiveness of China's food safety regulatory governance will also impact the global food supply chain and public health.

To tackle with dual political and economic pressures from domestic and abroad, Chinese government set about reorganizing its food safety regulatory regime and strengthen regulatory policy enforcement in 2013. Two rounds of regime remodeling were carried out to make its formerly fragmented structure more coordinated in 2013 and 2018. Nowadays, the State Administration for Market Regulation (SAMR) has become the most important regulator in food safety together with two other supporting agencies:, the Ministry of Agriculture and Rural Affairs (MARA) and the National Health Commission (NHC). Meanwhile, while first enacted in 2009, the Food Safety Law (FSL) was amended quickly to toughen its standards, regulations, penalties and accountability in 2015 and 2018. On one hand, food producers, manufacturers, traders, and restaurant owners have had more responsibilities imposed to ensure their products' safety. On the other hand, more regulatory power and accountability has been granted to local authorities to minimize food safety risk within their jurisdictions. Although these abovementioned policies matter, in partially improving food safety regulatory effectiveness, a series of structural factors in central-local relations, market regulation, and state-society collaboration still threaten its policy implementation effect. Therefore, food safety regulatory governance has provided a valuable window to examine the process, effectiveness, and political logic of China's state governance. Also, it generates a series of experiences and lessons for other countries and even for global health governance.

As a promising and potential research theme, food safety governance in China has attracted many scholars who have conduct insightful studies. After a careful collection and review of existing articles, we can summarize the literature into four groups with different perspectives. Firstly, a few experts explore China's food safety governance from

1 "Central Conference on Rural Affairs Held; Xi Jiping and Li Keqiang Made Important Speeches [English translation]," The Central People's Government of the People's Republic of China, December 24, 2013, accessed April 22, 2019, http://www.gov.cn/ldhd/2013-12/24/content_2553842. htm; "Xi Jinping 's Important Instructions on Food Safety Work," News of the Chinese Community Party, accessed October 21, 2016. 
the structural perspective. Liu (2010) offers an analytical framework that distinguishes three regimes in the history of China's food safety governance. He discussed the features, advantages, disadvantages, and development tracks of these regimes, and laid the groundwork for an analysis of China's emerging regulatory state. Similarly, Liu, Mutukumira, Anthony, and Chen (2019) divided the evolution of China's food safety regulatory system into five stages, claiming that it has been changed from traditional hierarchical supervision into cooperative regulation. It advances a conceptual framework to include policy stakeholders, regulatory technique, and enforcement system, stressing that consumer organizations and third-party test institutions will play more important roles in the future.

Secondly, lots of scholars focus more on striking issues such as policy-making and implementation from the policy perspective. Broughton (2010) focuses on policies and regulatory practices for aquaculture food safety in China and finds that regulations pertaining to antibiotic use are not complied with very closely. He points out the poor coordination that has partially caused regulatory problems in food safety governance and suggests that the central authority should implement more collaborations with local regulators. Han (2015) gives high praise to the newly-amended FSL, which reflects a transformation from government-centered administration to collaborative governance, and developed a series of policy suggestions on collaborative governance to promote its implementation.
Thirdly, more and more researchers have shown their interests in observing food safety governance in China from the international comparison dimension. After a general and theoretical narration based on international experiences, Yasuda $(2015,2018)$ contributes scholarship on food safety regulation failure in China to the politics of scale, and emphasizes that its massive production system, unwieldly bureaucracy, and geographic size bring fundamental policy challenge. Therefore, it is suggested that China's food safety regulatory reform should change its traditional unitary system and adopt a multilevel governance strategy to avoid regulatory failure. By means of comparing China's and Europe Union's (EU) food safety regulatory systems from the perspective of co-regulation, Chen, Wang, and Song (2017) argue that the public-private partnership model adopted by the EU's food safety regulatory system caould help strengthen China's food regulatory regime. They indicate that the success of co-regulation in the food regulatory system would bring significant benefits and opportunities for China, and argue that China should improve the private sector's effectiveness in co-regulating food safety.

Finally, there is a new trend to explain regulatory phenomena from the behavioral and cultural perspective. Being different from the mainstream literature on regulatory policies or institutions, Zhang and co-authors (2015) focus on how to rebuild consumers' trust in food safety in China. Taking Beijing as thea case study, they 
find consumers' trust deficiency has become even worse, although their main trustworthy food safety information come from government. To ensure its sustainable and safe food supply, it is suggested that China should build its food safety trust system by relying more on market and societal organizations than a single source from government. Another important research focus is on the information dissemination via mass media and its impact on consumers' perceptions and purchasing behavior. By examining food scandals surrounding yogurt and jelly products, Peng and colleagues (2015) argue that the information disclosure of food scandals impacts consumers' expected functions and purchasing behavior. Meanwhile, the decline of food sales and negative impacts on a food brand's reputation can elicit food manufacturers to push quality improvement.

The above four campsareas of research help us understand and explain China's food safety regulatory system from diverse perspectives, but they are limited in depicting a comprehensive picture of China's food safety regulation. It is thus imperative to develop a more nuanced theoretical framework to better understand and explain China's food safety regulation.

\section{Defining Fragmented Absorptive Regulation: A Conceptual Framework}

o introduce a new conceptual
framework to understand any
socioeconomic phenomenon, we need to identify possible analytical dimensions first. Essentially, food safety regulation is a part of social regulation that should strike a balance among politics, industry and science. In addition, we can also examine social regulations from two major dimensions: internal coordination within the state and $\boldsymbol{e x}$ ternal cooperation outside the state.

Internal coordination generally includes two parts: the first is horizontal, which means policy coordination among various regulators in the same level of authority; the second is vertical part which indicates power distribution and sharing between central and local regulators among a multilevel government. If both parts are well-coordinated, we can define it as a coordinated regime; otherwise it is termed a fragmented regime.

For external collaboration, a system can be divided into two-fold, state-market relation and state-society regime, which stresses a mutual collaborative pattern among state, market, and society. When state can pursue an effective collaboration with both private firms and societal organizations, we regard it as a collaborative regime. However, if state can play a predominant role over market and societal organizations, it can be defined as an absorptive regime since governmental agency has a strong capacity to impose its impact to both sectors.

If we draw a table based on coordination and collaboration degree of those two dimensions, we can develop a matrix to define four types of regulatory regimes (see Table 1). 
Table 1. The Framework of Internal Coordination and External Collaboration

\begin{tabular}{|c|c|c|c|}
\hline \multicolumn{2}{|c|}{ Dimension } & \multicolumn{2}{c|}{ Internal Coordination } \\
\cline { 2 - 4 } & High & Low \\
$\begin{array}{c}\text { External } \\
\text { Collaboration }\end{array}$ & High & $\begin{array}{c}\text { I } \\
\text { Coordinated-Collaborative } \\
\text { (E.g., financial regulation) }\end{array}$ & $\begin{array}{c}\text { Fragmented-Collaborative } \\
\text { (E.g., environmental } \\
\text { regulation) }\end{array}$ \\
\cline { 2 - 4 } & Low & $\begin{array}{c}\text { III } \\
\text { Coordinated-Absorptive }\end{array}$ & $\begin{array}{c}\text { IV } \\
\text { Fragmented-Absorptive } \\
\text { (E.g., food safety regulation) }\end{array}$ \\
\hline
\end{tabular}

A Type I regime (the coordinated-collaborative regulation) means there is a well-coordinated pattern among various regulators and a highly-collaborative model for those three sectors. A typical case for a Type I regime is China's current financial regulation, since its regulatory system is relatively centralized both in horizontal and vertical levels. Also, the Banking and Insurance Regulatory Commission has well-developed collaborations with related firms and social organizations.

In a Type II regime (the fragmented-collaborative regulation), the practice of China's recent environmental regulation demonstrates exactly how it is fragmented inside regulators but more cooperative among state, market, and social actors. Besides, as a highly-professional regulatory field, China has centralized its drug safety regulation both on horizontal and vertical levels for almost two decades, thus it may be coordinated for internal side; however, political participation in regulatory policy-making of pharmacies, clinics, and industrial associations is still limited, which can be defined as a Type III regime of the coordinated-absorptive regulation.

Food safety regulation can be defined as a Type IV regime of the fragmented-absorptive regulation, which signifies a low coordinated internal system and a state-led external structure. On the horizontal level, although SAMR has become a leading actor in food safety regulation, the other two agencies (MARA and NHC) still have ambiguous and overlapping boundaries with SAMR on agricultural products safety regulation and food safety standard-setting. On the vertical level, there is still lack of a clear division of labor and power allocation system among the multilevel government, even if a more decentralized regime has been developed since 2008. Moreover, food manufacturers and firms have still weak capacity to voice their opinions in regulatory policy making due to the low concentration ratio of China's food industry. In contrast to the high involvement of citizens in 
environmental and ecological protection, public participation in the food safety field is still inadequate due to its high professionalism and low collective mobilization of consumers.

Being different from the other three types of regulatory regimes, the fragmented-absorptive regulation has two seemingly contradictory sides: on one side, it demonstrates a relatively low efficiency regulatory process since it has to spend more policy resources on internal coordination. On the other side, in contrast to the weakness of market and social organizations, state capacity is stronger in accounting for its high state authority. Therefore, food safety regulation in China still seems like a state-centered model, but it is quite fragmented, so we cannot tell which organization can enforce its regulation on behalf of the state.

The concept of fragmented-absorptive regulation is insightful and useful to help us understand many unique phenomena and behaviors not only in food safety regulation in China, but also in many other sectors outside China as well. The five articles included in this special issue can be connected to the fragmented-absorptive regulation in some ways to reveal the logic and working processes of China's regulatory regime.

\section{The Articles in This Special Issue}

The fragmentation-absorptiveness regulation framework is a unique and complicated regula- tory regime which needs to be studied further. This special issue is particularly designed to help readers understand this new type of regulatory regime. The five articles included in this special issue explore China's food safety regulatory regime from diverse perspectives, which provide a blueprint to map the fundamental logic of this regime.

There are few studies to put China's food safety regulation in an international comparative context due to its unique characteristics; however, a multilevel governance approach should be an insightful perspective through which to observe the essential logic of China's food safety regulation. Yasuda's (2020) article makes a great attempt to compare China's food safety regulatory structure with its counterparts of EU, India, and the United States. He employed the concept of Macro-Governing Framework (MGF) to define the regulatory regimes of those four countries and regions: fragmented unitary (China), multilevel (EU), decentralized federal (India) and centralized federal (US). On the basis of this systematic comparison, he argues that each system has its advantage and weakness, so the reform of China's food safety regulatory regime should overcome its shortcomings based on its MGF. In fact, he mainly focuses on the internal part of China's food safety regulatory regime from both horizontal and vertical dimensions, which stresses how a fragmented system in a unitary system impacts its food safety regulatory effectiveness.

Although multiple-cases comparison is an insightful approach, it 
is more profound to make a two-case comparison to explore any single country's situation. By employing an analytical framework of monitoring space, An (2020) discusses two important parameters for social organizations' monitoring in China and UK's food safety regulatory processes. She finds that in China, general public forces such as mass media and the public play an important role, while third-party certification bodies seem more significant in UK. The author contends that it is necessary for each country to maintain their monitoring space in terms of their own regulatory context. She defines the structural differences between both countries, which explain how their social forces influence state regulatory styles. She claims that China's social force seem less professional but more societal than in the UK; however, the effect of its monitoring process needs to be improved due to its weak policy impact. These findings can also be included into the fragmented-absorptive regulatory framework to explain the state-society interaction.

As An's (2020) article mentioned, both mass media and the public play a crucial role in China's food safety regulatory governance, but we are still curious about how news reports from mass media affect citizens' perceptions of food safety, which will impose social pressure on local regulatory reform (Liu \& Ma 2016). Hongchuan Wang and Liang Ma (2020) use empirical data from a national survey and a dataset on media reported food safety scandals, exploring the effects of media coverage of food scandals on citizens' food safety perceptions. Their findings suggest that the frequency and scale of media-reported scandals can greatly affect citizens' food safety perceptions. Citizens in cities with more media coverage of food scandals are less satisfied with food safety, which reveals that mass media play an important role in forging public perceptions of food safety. Actually, this finding is not surprising at all since it is a byproduct of the risk communication deficit in China's food safety regulation (Ma \& Liu 2019). Since the regulatory authority has an apparent advantage over social actors in the fragmented-absorptive regulatory regime, it looks to produce a timely and friendly risk communication with mass media and individual citizens. Their policy implication to strengthen its communication capacity in mitigating citizens' concerns of food safety should be treated more seriously in the future.

To cope with food safety governance challenges, China has determined to build a more efficient regulatory system by restructuring its regulatory agencies since 2008. Most existing studies focus on horizontal coordination among multiple regulators, and few of them explore the restructuring process from the perspective of central-local relations. By observing the reconstruction of China food regulatory agencies in 333 prefecture-level cities, Zhipeng Liu and Peng Liu's (2020) article explores an interesting research question: what factors contribute to the acceptance of reform by a government and encourage that government to adopt agency reconstruction? It has changed our conventional impression 
that China's administrative agency setting should be exactly alike from central to township hierarchically because of its unitary system. They find that the scale of food markets, the abundance of regulatory resources, and policy learning pressure from surrounding cities are crucial factors to push any local authority to accept the central reform agenda. The purpose of this research is to explore what factors contribute to the chaotic and varied regulatory agency structures under China' unitary system, which help us understand the political logic of the fragmented-absorptive regulation more clearly.

All five articles in this issue have studied certain issues from a structural dimension, but we are still wondering about the evolutionary trajectory of the fragmented-absorptive regulatory regime in China's food safety governance. By using a social network analytic method, Guochong $\mathrm{Xu}$ and Longxia Huo (2020) attempt to draw a road map of the collaborative networks of Chinese food safety regulation from 2004 to 2017. They find the role of governmental agencies has gradually changed from dominant leader to key supporter. In addition, the former China Food and Drug Administration (CFDA) has become a crucial component within the regulatory network through which regulatory coordination has been effectively improved. Their main argument reveals that the early version of the fragmented-absorptive regulatory regime is even more fragmented and absorptive than the current version. Also, Chinese top leaders have realized the limitations and problems of this regulatory regime and decided to improve it to adapt to new regulatory challenges. However, this reform process may be a long process due to its unique administrative regime, industrial structure, and civil society.

\section{Conclusion}

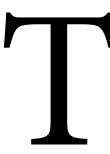
The building of a Chinese regulatory state is an indispensable part of global regulatory reform, which has raised a series of novel questions to be studied by scholars. How can one build an effective and independent regulatory state? Why do regulatory regimes in different sectors differ from each other? How do we understand regulatory fragmentation phenomena in a unitary Party-state like China? How should we define and perceive the roles of market and social actors in the regulatory state building? If scholars can provide convincing answers to these research questions and make comparisons with other countries, they can produce new knowledge and theories to enrich our understanding of regulatory governance.

We introduce a typology matrix to define the regulatory regime from the dimensions of internal coordination and external collaboration. It is interesting that there are four types of regulatory regimes in different sectors within a single regulatory state. While the coordinated-collaborative mode of regulation might be the most ideal situationmodel, it also faces challenges in maintaining and sustaining its regulatory capacity. Similarly, the other three types of regulatory regimes face differ- 
ent challenges in regulating their industries. In other words, this conceptual framework is a generic model to depict any regulatory regime in a multilevel and multi-actor society.

We developed the conceptual framework of the fragmented-absorptive regulation to try to explore the questions above based on empirical studies on China's food safety regulation. In the food safety regulation field, the fragmented-absorptive regulation is among the most appropriate attempts to describe the current situation since it reveals the core characteristics of food safety regulation from both dimensions. The five articles in this special issue discussed key research questions on China's food safety regulation, and all of their foci and findings can be included into the fragmented-absorptive regulatory framework despite the fact that they differ with each other in research design, empirical data, and research method. We thus believe the framework can be a useful conceptual framework to understand China's food safety regulatory governance. Also, by classifying regulatory regimes into the two dimensions, the internal coordina- tion and external collaboration, we can explore the dynamics of the changing processes of regulatory reforms. For instance, food safety regulation in China can be improved upon through either strengthening internal coordination (e.g., structural changes both vertically and horizontally) or facilitating external collaboration (e.g., cross-boundary governance with industries, consumers, and/or media), or both.

Certainly this new conceptual framework has a great potential to be improved upon in future studies, and a series of issues like the measurement of fragmentation and absorptiveness, the driving forces to foster this regime, the transformation and future development of the fragmented-absorptive regulation, and the extension of this conceptual framework to other sectors could be explored. We call for future studies to pay attention to this conceptual framework and use it in empirical explorations. Hopefully this conceptual framework will not only make sense to understand and explain China's food safety regulations, but also provide insightful to understand regulatory reforms in other sectors and countries.

\section{References}

An, Y. (2020). Evaluating the “"Monitoring Space”" in Food Safety Regulation: A Comparison Between China and the United Kingdom. China Policy Journal, 2(1). https://doi.org/10.18278/cpj.2.1.2

Broughton, E. I., \& Walker, D. G. (2010). Policies and practices for aquaculture food safety in China. Food Policy, 35(5), 471-478. https://www.sciencedirect.com/ science/article/abs/pii/S0306919210000606. 
Han, Y. (2015). A Legislative Reform for the Food Safety System of China: A Regulatory Paradigm Shift and Collaborative Governance. Food and Drug Law Journal, 70(3), 453-480. Retrieved August 15, 2021, from https://www.jstor.org/stable/26661075

Liu, P. (2010). Tracing and periodizing China's food safety regulation: A study on China's food safety regime change. Regulation \& Governance, 4(2), 244-260.

Liu, P., \& Ma, L. (2016). Food scandals, media exposure, and citizens' safety concerns: A multilevel analysis across Chinese cities. Food Policy, 63, 102-111. https:// doi.org/http://dx.doi.org/10.1016/j.foodpol.2016.07.005

Liu, Z., \& Liu, P. (2020). The Antecedents of Restructuring of Regulatory Agencies: An Empirical Study of Prefecture-Level Food Regulation Departments in China. China Policy Journal, 2(1). https://doi.org/10.18278/cpj.2.1.4

Liu, Z., Mutukumira, A. N., \& Chen, H. (2019). Food safety governance in China: From supervision to coregulation. Food Science \& Nutrition, 7(12), 4127-4139.

Ma, L., \& Liu, P. (2019). Missing links between regulatory resources and risk concerns: Evidence from the case of food safety in China. Regulation \& Governance, 13(1), 35-50. https://doi.org/doi:10.1111/rego.12160

Mol, A. P. (2014). Governing China's food quality through transparency: A review. Food Control, 43, 49-56. https://www.sciencedirect.com/science/article/abs/pii/ S0956713514001030.

Peng, Y., Li, J., Xia, H., Qi, S., \& Li, J. (2015). The effects of food safety issues released by we media on consumers' awareness and purchasing behavior: A case study in China. Food Policy, 51, 44-52.

Wu, X., Yang, D. L., \& Chen, L. (2017). The Politics of Quality-of-Life Issues: Food Safety and Political Trust in China. Journal of Contemporary China, 26(106), 1-15. https://doi.org/10.1080/10670564.2017.1274827

Wang, H., \& Ma, L. (2020). Media Coverage and Citizens" Perceptions of Food Safety in Urban China. China Policy Journal, 2(1). https://doi.org/10.18278/ cpj.2.1.3

Xu, G., \& Huo, L. (2020). From Administrative Domination to Administrative Leadership: The Evolution of Food Safety Collaborative Regulation in China. China Policy Journal, 2(1). https://doi.org/10.18278/cpj.2.1.5 
Yasuda, J. K. (2015). Why food safety fails in China: The politics of scale. The China Quarterly, 223, 745-769. https://doi.org/doi:10.1017/S030574101500079X

Yasuda, J. K. (2018). On Feeding the Masses: An Anatomy of Regulatory Failure in China. Cambridge University Press.

Yasuda, J. (2020). Regulatory Scaffolding: Food Safety Politics in Federal, Unitary, and Multilevel Systems. China Policy Journal, 2(1). https://doi.org/10.18278/ cpj.2.1.1

Zhang, L., Xu, Y., Oosterveer, P., \& Mol, A. P. (2016). Consumer trust in different food provisioning schemes: evidence from Beijing, China. Journal of Cleaner Production, 134, 269-279. 